\title{
The Hajj From West Africa From a Global Historical Perspective (19th and 2oth Centuries)
}

\author{
Baz Lecocq \\ Ghent University, Belgium \\ baz.lecocq@ugent.be
}

\begin{abstract}
Over the last years, in average, 2,1 million people per year performed the hajj. These millions stand in contrast to the numbers visiting Mecca half a century ago. On average, until 1946 a rough 60,000 pilgrims visited Mecca annually, with at least half of these coming from the Arabian Peninsula. Today Saudi nationals make up about a quarter of all pilgrims. The explanations for the staggering thirtyfold increase in total pilgrims, and the even more spectacular growth of the number of foreign pilgrims in slightly more than half a century are quite simple. First of all, the increasing world population in general led to larger numbers of pilgrims. Second, the journey became safer and better organised during the 2oth century. In those parts of the Muslim world where it was not already (the Ottoman Empire), the organisation of the hajj became a state affair, organised first by the colonial authorities, and by the postcolonial states afterwards. Third, despite growing disparities in the distribution of global economic wealth an increasing number of Muslims could afford to pay for the journey. And finally the availability of cheap mechanical mass transport increased over this time period. This paper will look at these interconnected reasons for the spectacular growth of the hajj in the past half century from a world historical perspective, focussing on the West African Sahel in the 19th and 2oth centuries. In this paper I hope to sketch how state rule, changing economies, motorised mass transport, and religion are interconnected phenomena, which are all shaped by and giving shape to world historical events in the Muslim world. The focus will be largely on the changing demography and social geography of the pilgrimage journey to Mecca as performed by pilgrims from the Sahel, and the changing significance of this journey in their lives.
\end{abstract}

\section{Keywords}

hajj, Sahel, pilgrimage, colonial and postcolonial state

\section{Résumé}

Au cours des dernières années, environ 2,1 millions de personnes se rendent à La Mecque en pèlerinage chaque année. Ce nombre contraste avec le nombre de pèlerins d'un demi-siècle en arrière. Jusqu'en 1946 il y avait à peu près 60 ooo pèlerins qui visitaient La Mecque chaque année, la moitié d'entre eux provenait de la péninsule arabique elle-même. Aujourd'hui les Saoudiens ne représentent qu'un quart du total de tous les pèlerins. Les explications pour la multiplication 
stupéfiante du nombre total de visiteurs, et du nombre encore plus spectaculaire de pèlerins étrangers sont très simples. D'abord, l'accroissement général de la population mondiale se traduit par un plus grand nombre de pèlerins. Deuxièmement, au cours du XXe siècle, le voyage est devenu plus organisé et moins dangereux. Au-delà des pays musulmans où c'était déjà le cas, notamment dans l'Empire ottoman, l'organisation du hadj s'est transformée en une affaire d'état; coordonnée d'abord par les autorités coloniales et ensuite par les états post-coloniaux. Troisièmement, malgré les disparités dans la répartition de richesses économiques au niveau global, un plus grand nombre de musulmans sont en mesure de payer le voyage. Finalement, pendant cette période, le transport en masse mécanique est devenu de moins en moins cher, donc plus disponible. En se concentrant sur le Sahel de l'Afrique de l'Ouest des XIXe et XXe siècles, cet article vise à analyser, d'une perspective d'histoire globale, ces nombreuses questions liées les unes aux visà-vis de l'accroissement spectaculaire du hadj au cours du dernier demi-siècle. L'auteur cherche ainsi à ébaucher les interconnexions entre les régimes, les économies changeantes, le transport en masse motorisé et la religion. Tous ces phénomènes sont façonnés par, et façonnent à leur tour, les évènements de l'histoire du le monde musulman. L'accent sera mis sur la croissance démographique et la géographie sociale du pèlerinage vers La Mecque, tel qu'il est effectué par les pèlerins du Sahel, de même que sur la signification changeante de ce voyage dans leurs vies.

Mots-clés

hajj, Sahel, pèlerinage, état colonial et postcolonial

\section{Introduction}

The hajj, the pilgrimage to Mecca, is among the largest annual gatherings in the Muslim world. Its importance in the lives of individual Muslims, as well as for the Muslim world, cannot be overestimated. The hajj is first and foremost the performance of the prescribed religious rituals in Mecca, but it can be seen as the pilgrimage itself, the journey to and from the holy places. ${ }^{1}$ The latter meaning is central to this paper.

Over the last years, on average, 2.1 million people per year have performed the hajj. ${ }^{2}$ These millions stand in contrast to the numbers visiting Mecca only half a century ago. For the first half of the 2oth century until 1946, on average roughly 60,000 pilgrims visited Mecca annually, with at least half of these pilgrims coming from the Arabian Peninsula. ${ }^{3}$ Today Saudi nationals make up about a quarter of all pilgrims. The explanations for the staggering thirtyfold

1) 'Hadjdj,' Shorter Encyclopedia of Islam (Leiden: Brill 1953), 121-125.

2) Kingdom of Saudi Arabia, Ministry of Hajj, Hajj and Umrah Statistics. http://www.hajinformation. com/main/l.htm. Last accessed 15/10/2011.

3) Botte (2010: 99). Faroqhi (1994: 46) lists numbers in the 200,000 for the 16th and 17th centuries, with a decrease in the 19th century, possibly explained by the influence of colonial conquests and subsequent economic downturns in the Islamic world. 
increase in total pilgrims, and the even more spectacular growth of the number of foreign pilgrims in slightly more than half a century are quite simple. First of all, the increasing world population in general led to larger numbers of pilgrims. Second, the journey became safer and better organized during the 2oth century. ${ }^{4}$ In those parts of the Muslim world where it was not already (the Ottoman Empire), the organization of the hajj became a state affair, organized first by the colonial authorities, and by the postcolonial states subsequently. ${ }^{5}$ Third, despite growing disparities in the distribution of global economic wealth, an increasing number of Muslims could afford to pay for the journey. And finally the availability of cheap mechanical mass transport increased over this time period.

This paper will look at these interconnected reasons for the spectacular growth of the hajj in the past half century from a world historical perspective, focusing on the West African Sahel in the 19th and 2oth centuries. In this paper I hope to sketch how state rule, changing economies, motorized mass transport, and religion are interconnected phenomena, which are all shaped by and giving shape to world historical events in the Muslim world. A broad sketch of economic developments in Africa during this period will provide the background to these arguments, but the focus will be largely on the changing demography and social geography of the pilgrimage journey to Mecca as performed by pilgrims from the Sahel, and the changing significance of this journey in their lives.

The West African Sahel is a region with a long history of Islamic presence and a long-standing pilgrimage tradition. Up until today the region furnishes the largest number of African pilgrims to Mecca despite its geographical distance. ${ }^{6}$ Both the increase in the number of West African pilgrims in recent centuries and its causes broadly follow patterns parallel to those in other parts of the world, but I would like to sketch three important West African specifics.

The first is related to the broad macro economic and demographic history of the region. ${ }^{7}$ In the late 19 th century the Sahel was in political and economic turmoil despite favorable climatic circumstances. The abolition of the transAtlantic slave trade altered the political, social, and economic landscape of the Western Sahel, giving rise to the Jihad states of the 19th century and

\footnotetext{
4) Birks (1978); Bawa Yamba (1995).

5) Bianchi (2004); Christelow (1987); Faroqhi (1994); Loimeier (1988); Medugbon (1982).

6) This study will focus on the pilgrimage from the Francophone Sahel.

7) The timing varies between the Senegalese coast, where European presence was much earlier established and more direct, and Niger and Northern Nigeria, where European presence was established much later.
} 
changing the production and consumption of slaves. At the same time, the rising demand for slaves in Egypt and the Indian Ocean region, and the subsequent Egyptian colonization of Sudan gave rise to new patterns of slave trade and consumption in the Eastern part of the Sahel and Central Africa, and ultimately led to the foundation of the Mahdist state. ${ }^{8}$ Colonial conquest brought new upheaval, coinciding with a period of bad climatic conditions, drought, and famine. Recovery started everywhere with the creation of new transport infrastructures, especially railway lines, and the successful introduction of cash crops, especially peanuts and cotton. This process started first in Senegal, where the introduction of peanuts dates from the mid-19th century. ${ }^{9}$ It more or less ended in Niger in the mid-1930s, where peanut growing was deeply connected to the peanut industry in Northern Nigeria. The new colonial 'open economy' had its victims and its setbacks. ${ }^{10}$ But the colonial economic reorganization also gave access to monetary wealth to a larger group of agricultural producers and it led to the restructuration of the West African merchant class to whom Islam was a pivotal part of their identity. Combined with new state structures it further led to the creation of a new class of professionals of all kinds: from railroad and dockworkers, via professional soldiers, to mid-level bureaucrats. More importantly, the new cash crops and colonial labor policies, including the abolition of slavery in the 2oth century, led to the creation of a class of mobile agricultural laborers (infra). The monetary economy of which they were part allowed these new groups of potential Muslim pilgrims to travel by new means of transport, in new political settings.

A second observation is that the growth in the number of West African pilgrims is less due to demographics than to conversion. West Africa witnessed a mass conversion to Islam from the early 2oth century onwards. After the Jihad states of the 19th century had further increased the potential realm of Islam in West Africa, the number of Muslims increased spectacularly under colonial rule under paradoxical circumstances. Islam had been present in the Sahel as a social cultural and political force since the 8th century $\mathrm{AD}$, but in large parts of the region Muslims had always remained an influential yet small minority. However, the French colonial administration perceived the region as 'Muslim' and therefore restricted Christian missionary work. At the same time it saw Islam as a higher form of civilization than still existing local cults. It therefore looked benevolent upon further Muslim conversions, which took place en

\footnotetext{
8) Klein (1998); Lovejoy (2005); Searcy (2010).

9) Cruise O'brien (1971).

10) Hopkins $(1973 ; 2009)$.
} 
masse, largely as a reaction to colonial rule. ${ }^{11}$ There is a second paradox. Colonial conquests had made the Sahel an unsafe place, but colonial rule made it safer and politically submitted but stable. It ended cycles of warfare and mass enslavement that had made traveling over land a hazardous endeavor. After the colonial pacification of the Sahel, notable changes took place in the roads taken by the pilgrims, in line with increased safety, and the availability and technical possibilities of new means of transport, notably steamers and trains. As more faster and cheaper transport became available in the 1940s in the form of motorcars and airplanes, and as general African incomes, especially of the smallholder farmer and merchant grew in the 1950s, more and more of the growing number of African believers performed the hajj. This increase in pilgrims continued in absolute numbers in the 1970s, despite the decrease of wealth in Africa.

A third specificity for the pilgrimage as performed by West Africans stems from a combination of geography and Islamic law. African pilgrims could travel to Mecca entirely over land, even on foot if needed, and they were allowed to do so by the Maliki School of Islamic law most West Africans adhere to. According to the other three schools of Islamic law, the prospective pilgrim needs to have the means to procure transport and provisions superfluous to the actual costs of the journey, and to provide the provisions for dependent relatives at home while being away. Furthermore, anyone living more than three days' walking away from Mecca is obliged to have the means to procure transport. The Maliki school, however, holds that pilgrims can walk all the way to Mecca, regardless of distance; that they can work along the way to complement their provisions and means of transport; and that they do not need to have enough means for the return trip and the upkeep of relatives either. ${ }^{12}$ This means that West African pilgrims could leave on hajj without all the money needed to sustain them through their travels and walk the whole distance if they had to, while complementing the costs of the journey by working along the way. Due to these geographical and religious legal conditions, many West African pilgrims combined the hajj with labor migration, profiting from the fluctuations in the labor market, and taking years, even decades, yes sometimes even their whole life to arrive in Mecca and return home. ${ }^{13}$ In comparison, pilgrims from the Indonesian Archipelago perforce had to travel the largest leg of their journey by boat (or, later, airplane) and the most important legal school in Indonesia,

11) Launay \& Soares (1999); Peterson (2011); Zakari (2010).

12) al-Naqar (1972: xvii).

13) Bawa Yamba (1995); Birks (1978); Hino (1986). 
the Shafi'i School, is adamant when it comes to having all the means to pay the fares of one's return journey prior to leaving, and on leaving one's family with enough means to live in one's absence. ${ }^{14}$

\section{The 19th Century}

In the 19th century West African hajjis were mainly scholars, merchants, and rulers, who combined the hajj with religious study (either of Muslim sciences or of Sufi mysticism), trade, or political contacts. Their pilgrimage depended on the pilgrim's location, on his religious affiliation, his knowledge of the prevailing political situation in the regions he would travel through, the safety on the roads, his personal means, and his contacts in the larger world through trade, scholarship, or politics. In the 19th century a number of larger events influenced these choices.

In the 19th century West African pilgrims could join the large trans-Saharan caravans, which offered organization, safety, and the possibility of logistical support if needed. Starting in the early 18 th century, pilgrims from present-day Mauritania and the Western Sahara even started to organize a special annual pilgrimage caravan, in which whole families could travel to Mecca. ${ }^{15}$ Taking the trans-Sahara road allowed richer pilgrims to take the boat from the North African coast, which was faster and more comfortable than traveling over land. Already in the 18 th century, maritime powers, notably France and Britain, but also lesser powers such as the city-state of Dubrovnik, were engaged in the transport of pilgrims. These were happy to travel aboard the vessels of the unbelievers as they were less prone to pirate attacks. ${ }^{16}$ Traveling across the Sahara allowed West African pilgrims to connect with centers of religious learning in North Africa, such as the Qarawiyyîn, Zeytûna, and al-Azhar universities. With the slow rise of the Tijaniyya Sufi brotherhood in West Africa, pilgrims of that affiliation combined the hajj with visits to the tomb of Cheick Ahmad Tijani, the founder of their order, in Fes. Finally, if well timed, traveling trans-Sahara to Cairo allowed pilgrims to travel with the renowned Mahmal caravan, carrying the black shroud covering the $K a^{\prime} a b a$, which is renewed every year and which was made in Egypt until 1952. ${ }^{17}$

\footnotetext{
14) Juynboll (1930).

15) Lydon (2004: 43).

16) Faroqhi (1994).

17) 'Mahmal,' Encyclopedia of Islam vol. 6 (Leiden: Brill 1986: 44-46).
} 
But crossing the Sahara remained a dangerous endeavor. Caravans could get lost and die of thirst if water wells were not reached in time or had dried up. They could be pillaged and routed, or be buried in a sandstorm. Political factors were important as well. The rising unrest in the Mediterranean during the Napoleonic wars made sea voyages on European ships far less safe. The wars between the Egyptian Khedive Mohammed 'Ali and the Wahhabi Saudi's on the Arabian Peninsula in the early 19th century disrupted the Mahmal caravans from Egypt and heightened insecurity. ${ }^{18}$ Feelings of safety declined further with the subsequent European conquest of North Africa, announced with the occupation of Egypt in the Napoleonic wars, followed by the conquest of Algiers by France in 1830 and of Tunis in 1871, and by the British occupation of Egypt in 1882. The decline of the trans-Saharan trade in that same period and partly for the same reasons made traveling along these roads even less attractive as pilgrimage and trade became slowly disconnected. ${ }^{19}$ The French colonial conquest of the Sahara in the late 19th century made traveling along Saharan roads even more dangerous.

Hence the trans-Sahara road slowly gave way to the trans-Sahel road, which offered different challenges and opportunities. The full establishment of the Jihad States in the 19th century and the return of peace in the central Sahel led to more safety after centuries of insecurity (supra). Continued religious warfare and colonial conquests of the western Sahel did not so much impede as encourage people to leave the area, on hajj or as refugees. However, the Egyptian conquest of what is now the Republic of South Sudan in the 1820s, and the ensuing rise in slave trade in that area, as well as in Darfur, made traveling in the eastern Sahel more perilous again. ${ }^{20}$ In the late 19th century, the Mahdist state made this part of the Sahel slightly safer for a brief period, although the Mahdist regime had a tendency to recruit pilgrims into their armies based on the argument that jihad had replaced hajj as a central pillar of Islam. As a last factor of importance we need to mention the colonial conquest of the Sahel starting in the late 19th century, which disrupted trade, traffic and pilgrimage throughout the region. However, it caused many pious Muslims to flee their region of origin towards lands not yet conquered by the infidels. As these lands grew smaller and smaller, a number of these Muslims ended in the Hejjaz as muhajirs: religious refugees.

\footnotetext{
18) Sabini (1981).

19) Lydon (2009: 158).

20) Fisher (1988).
} 
All these circumstances and their effects on pilgrims' choices are clearly visible in the pilgrimages of two 19th-century West Africans whose accounts we have. The first and oldest account so far found of a pilgrimage along the Sahel roads is that of Al-Hajj Boubeker, a pilgrim who left his native Futa Toro on the Middle Senegal River in 1816. Instead of taking the trans-Saharan road directly to Morocco, Boubeker traveled to Djenné, probably for religious reasons, from where, probably through misguidance, he first traveled to Ségu. From there he traveled overland to Timbuktu, from where he wished to continue his journey through the Fezzan to Cairo via a non-specified road. In Timbuktu he learned about the inhospitality of the Saharan populations and the dangers and costs of the journey. As Al-Hajj Boubeker had no financial means and intended to accomplish his journey while living on charity, he decided to change course and follow the Sahel road. He first traveled back to Djenné, where he boarded a ship. He followed the Niger River, then the Sokoto River towards Katsina, and from Kano he followed the Hadeija and Komadugu Rivers to Lake Chad. From then on, he traveled through Bagirmi, Wadaï, Darfur, and Kordofan to Suakin. ${ }^{21}$ His decision to take the Sahel road instead of the trans-Sahara road reflects first of all Al-Hajj Boubeker's economic conditions as a poor Sufi beggar. But it also reflects some of the developments sketched above: the creation and consolidation of the Sokoto caliphate in the early 19th century, and the increase in commerce with European traders on the West African coast that had led to a gradual shift away from the trans-Saharan trade roads, where caravans declined in size, and towards east-west bound traffic along the Sahel.

A second pilgrimage that reflects the developments in the 19th century is that of Ahmad bin Thuwair al-Janna, who began his pilgrimage in $1829 .{ }^{22} \mathrm{He}$ first went from his native city of Wadân in present-day Mauritania to Walâta via Tichît, a city functioning as a gathering point for pilgrims. He then traveled to Morocco via the trade road to the Draâ valley passing Ligsayba. Ahmad's journey first makes a deep southward curve, which is explained by his need to collect some outstanding debts with his trade relations. To settle one's credits and debts before going on hajj is prescribed by Muslim law, but Ahmad could certainly use the money in any case. The official pilgrim caravan described above had already left so Ahmad joined an ordinary trade caravan. He traversed Morocco, where he visited the tombs of numerous Sufi saints, and then boarded a British ship in Larache bound to Alexandria via Livorno in Italy, where he spent 40 days in quarantine. Upon arrival in Alexandria, he

21) Boubeker \& Rouzee (1915).

22) Norris (1977). 
was quarantined for another eight days. The increasing connections between Europe, North Africa, the Middle East, and South Asia, notably through colonial conquests, but also through increased trade and the transport of South Asian pilgrims, had led to the rise of diseases such as cholera, which led both European and Ottoman powers to apply quarantine to travelers from the Muslim world. Ahmad noted these measures against his continued travel with some bitterness, and ascribed them to the growing weakness of the Muslim world in the face of Europe. ${ }^{23}$ In Suez he boarded a ship calling at Yanbu, from where he continued by camel to Medina and on to Mecca. He arrived in 1831, taking one and a half years to arrive. On the way back he traveled over land until Benghazi, and from there continued mostly by boat. He stopped for considerable periods in Cairo, Tunis, and Fez to visit the al-Azhar, Zeytûna, and Qarawiyyîn universities, or to buy books. He also made a stop in Algiers and Gibraltar in 1834, where he was literally hosted as royalty by the French and British authorities, who noted his arrival in their newspapers, hailed him with salutary gunshots, gave him presents, and inquired with interest about his country of origin. Especially the gun salute by the governor of Gibraltar made a favorable impression as this salute came from 'an enemy of Islam.' Ahmad attributes the generosity he received from the Christians to divine benevolence. ${ }^{24}$ A more worldly explanation would be the growing interest among European powers in the possibilities of further African conquests, which became a reality later that century.

\section{The 2oth Century}

From the twentieth century onwards, completely different factors came to play an important role in the performance of the hajj. Colonial conquests had made the Sahel an unsafe place, but colonial rule made it safer and politically submitted but stable. Safety or political and military turmoil were therefore no longer important considerations in the travels pilgrims undertook. By the time postcolonial conflicts broke out in the 1950s and 1960 in Chad and Sudan, air transport had become so common that these conflicts only played a role for the most pious: those who continued to travel on foot through the Sahel, instead of taking the heavenly road to Mecca. ${ }^{25}$ However, colonial rule had a

\footnotetext{
23) Ibidem, 25 .

24) Ibidem, 104.

25) Birks $(1975,1977,1978)$.
} 
tremendous impact on the pilgrimage in different ways, bringing new options and new choices for pilgrims, but also new obstacles.

Colonization brought along new concepts and practices of state, especially new concepts of administration and the legibility and surveillance of state subjects, the attempts at control of religious power, and the redistribution of wealth and power. To accommodate the hajj within these fields, colonial states, and postcolonial states afterwards, developed specific policies towards the hajj.

From the 1840s onwards, the hajj became an instrument of religious and social politics for the French empire towards its Muslim subjects in the Maghreb. Following the Dutch example in the Dutch East Indies, the French colonial authorities started to first regulate and then organize the pilgrimage. The reasoning behind these policies changed over time. First, interference was derived from land policies in Algeria. In 1840, the French state expropriated the awqâf: local religious foundations with a religious, social, and economic function. Following administrative logic, the colonial government therefore saw it as its duty to take up the functions previously held by the awqâf, one of which was the organization and financing of the hajj for a number of its constituents. ${ }^{26}$ From this followed that the French state paid the journey home for destitute Algerian pilgrims, and financed the construction of a hotel for French subjects in Mecca. ${ }^{27}$ The main reason for interference, however, was the desire to monitor the pilgrims. In the 19th and early 20 th centuries most orientalists were convinced that the hajj had a negative effect on the perceptions of colonial rule held by colonial subjects, and that these perceptions could be carried back home where they could upset the colonial order. ${ }^{28}$ This fear and its ensuing attempts at controlling the pilgrimage subsided somewhat by the end of the 1940s, although 'political Islam' remained a passionate concern for the officers of the Muslim Affairs Office (Bureau des Affaires Musulmans) until the end of colonial rule. ${ }^{29} \mathrm{~A}$ second concern, one for which the colonial authorities knew they were unable to find a definite solution, was the departure of pilgrims outside any form of state control. Lack of population registers and other means of state surveillance over subjects and the very possibility to travel over land to Mecca meant that unknown numbers of pilgrims left for the hajj without

26) Christelow (1987). The British, the Dutch, and the Soviet Union developed similar policies. So far, there exists no comparative study of these colonial hajj policies.

27) Christelow (1987); Mbacke (2005: 220).

28) Snouck-Hurgronje (2007).

29) Triaud (1997). 
any form of permission or papers. Measures to keep these 'illegal' pilgrims in control were ineffective throughout the colonial period, but were nevertheless put in place. ${ }^{30}$ Thus, control and legibility remained an important objective of the state, but was now complemented with motives of a more paternalistic attitude toward colonial subjects.

In the 1930s, control evolved into active engagement in organization. Already in the late 19th century did the colonial government in West Africa help to organize the hajj, by contracting French shipping companies such as Cyprien Fabre to facilitate cheap transport. ${ }^{31}$ From 1935 onwards, the colonial government began to organize an "official" hajj for West Africans by steamship, in line with a similar policy inaugurated in North Africa in $1931 .^{32}$ Departing from Dakar, West African pilgrims traveling with this state organized pilgrimage joined the official North African pilgrim convoy in Casablanca. At the end of World War II the colonial administration in French West Africa started to use airplanes in the organization of the official pilgrimage to transport a small number of high-ranking African hajjis, such as future Tunisian president Habib Bourguiba. ${ }^{33}$ In the early 1950 s this official hajj by airplane was extended to less important pilgrims through the intervention of commercial airlines, such as TAI, UAT, and Air France. Originally, the numbers of departing pilgrims were small, not surpassing a few dozen in the 1930s, but in the 1940s and 1950s the organization of the official hajj by the state grew to become one of the rare true services the colonial state was delivering to its subjects, used by about a few thousand French West African pilgrims a year in the 1950s.

The main reason for this state involvement in the organization of the pilgrimage was to give practical body to a particular discourse on the French colonial presence in the Muslim world. It was to promote a vision of a France benevolent to Islam and its Muslim subjects, projected outwards to a Muslim world perceived to be hostile to France. But through the creation of an image of a hostile outside Muslim world, the idea was also created of an inner Muslim world, a French Muslim world, inhabited by Musulmans français, who were

\footnotetext{
30) It is therefore impossible to give any meaningful numbers on the total amount of pilgrims from West Africa over the period concerned. Only the number of 'official' pilgrims (infra) could be known, but this is research still to be undertaken.

31) Mbacke (2005).

32) ANN 4E9.1 Pelerinage à la Mecque 1924-1934, and Christelow (1987).

33) Mbacké (2005) and ANN 4E12.12 Extraits du rapport du ministère des affaires étrangères sur le pèlerinage à la Mecque 1946. Bourguiba made the official pilgrimage by Junkers 52 airplane in 1946.
} 
supposed to be content with this status. ${ }^{34}$ These Muslims, as subjects of the French empire, had a right to protection, and a right to and freedom in practicing their faith, but as French Muslims. By organizing the pilgrimage and sponsoring the pilgrimage of influential religious leaders, such as the sheikhs of Sufi orders and reputed marabouts, the colonial state hoped to control these men further and positively influence their vision of France. Other categories who benefitted from the official hajj were active soldiers and veterans of outstanding service, 'traditional' chiefs and other high-ranking colonial personnel. In his speech at the departure of the official pilgrimage convoy from Dakar in 1946, the Governor General formulated this vision as follows:

You will meet many pilgrims of other nationalities. You will have to make an effort to be worthy representatives of France. Ifyou are permitted to leave, it is because the government is sure that where ever one speaks of France, you will show your pride in being her sons. ${ }^{35}$

After World War II, the organization of the hajj found a new ground. As the French welfare state was under construction in France, the state-subsidized official hajj, which yearly cost millions of francs, formed a colonial outpost of this welfare state. Just as French unemployed, sick, or unfortunate, were entitled to financial aid through insurance and social security, so should African pilgrims on hajj, from the outset, be protected against possible damage and perils through state organization. Organizing an official hajj became the outer consequence of a logic in which "French Muslims" had a right to an orderly, sanitary, and safeguarded "French" pilgrimage. ${ }^{36}$

The desire to make the pilgrimage controllable did not stop at the organization of the official hajj, nor was it the sole concern of the colonial bureaucracies. As indicated above, the introduction of large-scale and relatively fast mass transport of pilgrims in the 19th century, notably steamships, had led to waves of epidemics, especially cholera, across the globe. This had led to the first international regulations of pilgrimage transport and its related health issues at the initiative of the Ottoman Empire in 1894. Quarantine stations had been installed off the Egyptian, Sudanese, and Arabian coasts. With the improvement of vaccination methods, vaccinations became required for all pilgrims, to be given prior to departure. It was especially the Saudi kingdom that would impose more state control over the pilgrimage and the pilgrims as the number of pilgrims grew. In 1926, two years after the Saudis took control of Mecca,

\footnotetext{
34) Pervillé (1997) and Weil (2003).

35) Paris-Dakar 26/o9/1946, cited in Mbacké (2005: 247-48).

36) Mann \& Lecocq (2007).
} 
a Royal Decree made it obligatory for all pilgrims to hold passports indicating their nationality. ${ }^{37}$ The French and British authorities complied, but it posed them with a particular problem that grew more complex over the decades. Their colonial subjects had a nationality, but no citizenship, which in Europe is inherently bound to nationality and to the right to hold a passport. With the gradual transfer of political and civil rights between 1946 and 1958, the status of the required passport which French West African pilgrims held upon entering Saudi Arabia, changed and grew in status, until in 1958, all pilgrims held formal passports of the French state, indicating their (almost) full citizenship in the French Community. ${ }^{38}$ Apart from the vaccinations and the Saudi required passport, pilgrims demanding formal permission to leave on the hajj, regardless of their means of transport, had to pay a fixed caution to the Bank of West Africa to ensure the costs of their repatriation if this would become needed, as well as a sum of money that would be returned to them as traveler's checks upon arrival in Djeddah, so as to ensure them against theft. Furthermore, they had to provide proof of good conduct, and a number of other documents, including an application form, perhaps symbolic of colonial control (see Figure 1). ${ }^{39}$

The official hajj by airplane from West Africa was abandoned in 1952, when it was left to the free market. The colonial state simply stipulated conditions and arranged the paperwork. A similar trend was visible in North Africa, where the official hajj was abandoned and left to the free market in 1956. There, bus companies quickly took over the pilgrimage market. ${ }^{40}$ Private and state owned companies such as French Air France and UAT, but also Air Liban and Sabena competed in the organization of affordable charter flights to Mecca, ensuring a safe, quick, and comfortable trip. The introduction of the airplane had even greater consequences for the organization and scale of the hajj. The price of hajj travel diminished even further. Not only the sums to be paid for transport and lodging decreased (compared against those of boat trips). As total travel time decreased from months to days, the cost of maintenance of those left behind, as well as the amount of lost income and security in livelihood due to absence diminished considerably. These arguments hold even more strongly

\footnotetext{
37) National Archives of Mali (ANM) RNI-4 E-494 Circulaire relative au pèlerinage à la Mecque 1928.

38) Mann \& Lecocq (2007).

39) $\mathrm{ANN}_{4} \mathrm{E}_{3}{ }^{-15}$ Colonie du Niger, pelerinage à la Mecque 1951. Prior to the mid-1940s, demands did not take this form format, but consisted of short letters, often written by a local French administrator in the name of the subject filing the demand.

40) ANN 4E14.1 Circulaires au sujet de l'organisation du pèlerinage à la Mecque par voie aérienne 1951-1953. The official hajj by boat remained existent. Christelow (1987).
} 


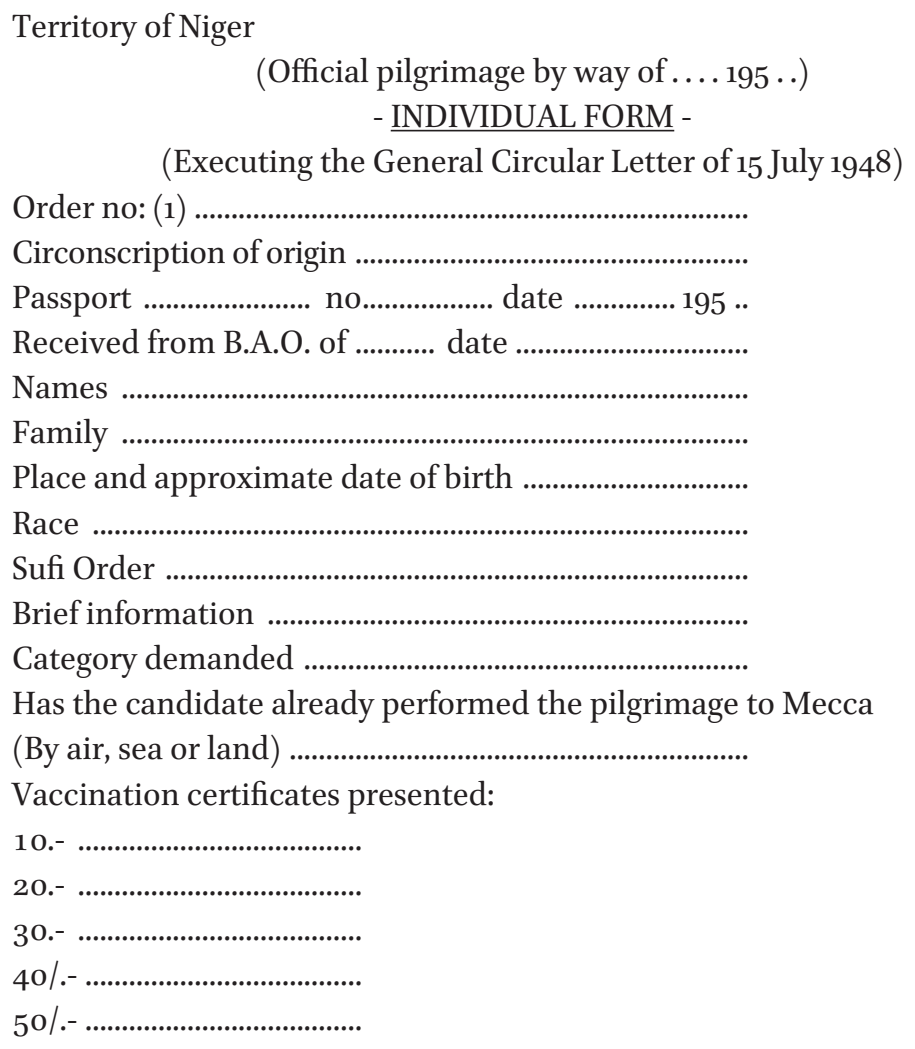

(1) Will be indicated in Capital

Figure r: The formal pilgrim form developed by the colonial authorities for the official hajj (supra).

for female pilgrims. ${ }^{41}$ Prior to World War II it was so exceptional for women to undertake the pilgrimage that when one did this became major news to the authorities and the community. But with the introduction of the steamship, their numbers already rose, as more women accompanied their husbands. ${ }^{42}$ The introduction of the motorcar led to a further rise for partly the same

41) Cooper (1999). Until WWII the vast majority of pilgrims were men. At present, over 50\% of pilgrims are women Unfortunately, I have no space in this article to elaborate on the very important gender dimensions to the changes in pilgrim demography and their meaning for individual pilgrims. This dimension requires an article of its own, which I hope to write in the future. 42) Mbacké (2005: 236). 
reasons. Women were expected to take care of their husbands on the journey. As labor migration became part of the overland journey, it became more desirable for couples to stay together. At present, more than $50 \%$ of all pilgrims in Mecca are female. ${ }^{43}$ This development is beyond doubt directly linked to the introduction of new means of transport.

From the perspective of a historian of West Africa, another element is interesting in the hajj by airplane: the prevalence of considerations of capital and enterprise over class, race, and colonial hegemony in the aeronautical hajj market. Those West Africans who could afford to pay the plane ticket were welcome aboard, without distinction of their colonial status as subjects or the consideration that they, not being white and European, should travel less comfortably. The racial distinction made in the colonial world on trains and boats between European and African passengers was not made. The hajj was simply far too interesting a market for the emerging civil aviation companies to leave unexploited. Given the general atmosphere of luxury, class, and wealth that surrounded air travel until the 1960 at least, and the absolute and relative costs of flying, the rise and decline of this market is further proof of the decline of the African economy since the 1950s. In the 1950s, when commercial passenger aviation took off, the African market was large and lucrative enough to be of interest to most European and Middle Eastern airlines. But despite the decrease in the costs of air travel in the decades since 1960, the relative number of African passengers has not risen as dramatically as in Europe, North America, or Asia, regardless of destination. Nevertheless, the market for aviatory pilgrimage rose in absolute numbers.

After independence, the post-colonial states of West Africa continued to organize the pilgrimage for their subjects. They did so partly for different reasons. Fear of anti-colonial ideologies no longer played any role, and neither did the idea of benevolence toward Islam as a discursive tool of Empire. Although more research in the post-colonial history of the pilgrimage is needed, it can be safely said that the main reasons can be found in the construction of political patronage, a clear continuation of the colonial period but its clientele grew and diversified. Apart from marabouts, traditional chiefs and army veterans, now loyal party members and the entourage of the head of state benefitted most from sponsoring, while the organization of the hajj by the state remained a small service rendered to the population at large. But where the application for the official hajj had been a bureaucratic procedure open to most in colonial times, it now became a more informal procedure, depending on contacts

43) Bianchi (2004): appendix tables. 
with the regime. Thus, in Mali in the 1970s, a number of influential businessmen managed to charter Air Mali airplanes for below cost prices to fly to Mecca on hajj, and even for some time every Friday to attend Friday prayers in Mecca. ${ }^{44}$ In post-colonial Niger, demands to benefit from the official hajj had to be made directly to president Diori. ${ }^{45}$ To make the difference from the colonial period clear, consider this formless but very formal letter written in post-colonial times:

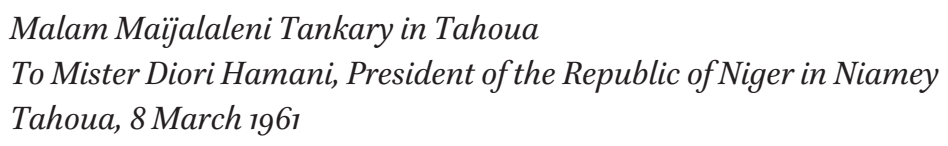

Dear Diori,

... I have been informed that you have inquired after me. I thank you for this compliment and I wish you an incomparable and unchangeable reign. I sincerely regret having missed you and I pray to God that your majesty deigns to reflect, as in the past, upon our unshakeable loyalty. You may forgive me my impertinence to ask you for a free return journey to Mecca. Thankyou. It is part of your grandeur to approve each "penurious" a free pilgrimage. ${ }^{46}$

From the 1980s onwards, the organization of the hajj became partly 'privatized' again. Competing with the state organized pilgrimage, specialized travel agencies offered package deals including all administrative arrangements, travel, and lodging, for prices starting at $\mathbf{1 . 5 0 0 . 0 0 0}$ CFA (in 2005). In both colonial and post-colonial times, those pilgrims who left with the official hajj but without having been invited by the state had to pay their fare. Together with the costs of vaccination, the passport, and other accompanying paperwork, this required a substantial amount of money not all pilgrims were able to pay up front. Therefore, many pilgrims, especially those inhabiting the Central Sahel, for whom traveling to Dakar to take the boat entailed traveling half way in the wrong direction anyway, kept travelling over land, taking the Sahel roads.

\footnotetext{
44) Amselle (1977); Hock (1999).

45) Observation based on research in the National Archives of Niger (ANN), series DAPA 226, 227, and 237: organization of the hajj in the 1960 .

46) ANN: DAPA 227 Pélerinage à la Mecque 1962. The French original read "musquine" for "penurious," which the reader had circled and translated "talaka": the Hausa word for the weak and needy, who usually seek patronage from the powerful.
} 
The most important explanation for this preference is that travel along these roads to perform the pilgrimage was linked to labor migration. This link is intimate and manifold. It cannot simply be stated that economic motives prevailed over religions ones in these journeys, or vice versa. According to Maliki law, pilgrims could earn the needed travel fare along the way, which meant poor Africans could set out for Mecca over land, while working on their way (supra). If gainful employment could be found for periods of time longer than necessary to pay for the next leg of the journey, then this of course tempted many pilgrims to prolong their stops. West Africans were well aware of the price of labor in large parts of Africa, and acted accordingly. ${ }^{47}$ Thus, in the 1930s, the road to Mecca led first south to Ethiopia. As part of their resistance tactics against the Italian occupation of their country, many Ethiopians refused to work on Italian infrastructural projects and plantations. The Italian government therefore attracted pilgrims cum immigrants with high wages. Pilgrims simply calculated that by traveling first to Ethiopia, the amount of time spent on labor along the way to and from Mecca could be considerably reduced, in comparison to working in either French or British colonies. ${ }^{48}$ The most durable and consistent labor stopover along the road to Mecca proved to be the Sudanese Gezira, where the large cotton plantations attracted large numbers of pilgrims. Many of these pilgrims left without vaccinations or legal papers. Maliki Muslim law stipulated they could do so since the ist century DH, but French, international, and especially Saudi laws of the 2oth century AD stipulated that they could not. Many pilgrims believed the sanitary and legal requirements were French or British inventions intended to stop pilgrims from performing their religious duties. Those who left without these requirements found out too late that the colonial powers had only complied with Saudi state demands and that their disobedience effectively blocked their access to Mecca. Returning home without the desired status of hajj was unthinkable for many of these pilgrims. Hence, many never reached Mecca and never returned home, becoming 'permanent pilgrims,' as Bawa Yamba called them, living their lives as labor migrants in Sudan, Chad, or elsewhere. ${ }^{49}$ In this way, religious and economic motives combined to shape people's live trajectories along the trans-Sahel road.

A second explanation for the preference for the trans-Sahel roads is the introduction of new means of transport in the Sahel, especially the train. These

\footnotetext{
47) Gary-Tounkara (2003).

48) ANN 4E1o.8 Rapports sur les pelerins venant de la Mecque 1930-1936.

49) Bawa Yamba (1995: 142-43).
} 
railways were primarily intended to evacuate cash crops from the Sahel to the coastal ports. In French West Africa, the construction of the railway lines from Dakar to Saint Louis and to Bamako, between 1881 and 1934, ensured the transport of peanuts and cotton to Europe. The railway line from Kano to Lagos, completed in 1911, served as the main transport outlet for both Nigerian and Nigerien peanuts and other crops. ${ }^{50}$ In Sudan, the railway line connecting Port Sudan at the Red Sea coast with El Obeid in Kordofan was constructed between 1906 and $1911 .{ }^{51}$ Although primarily intended for military and commercial purposes, these railroads did transport passengers. It was especially the Sudanese railroad, linking the Central Sahel directly to the Red Sea coast that attracted pilgrims to the trans-Sahel roads. Until the 1930s, pilgrims traveled essentially on foot or mount and pack animal and, in Nigeria, sometimes by train, to the Sudanese railway head at El Obeid and, if they could afford it, from there by train to the ports of the Red Sea. Those who could not afford the ticket simply followed the tracks. The growing road transport sector in both French West Africa and Nigeria, connected to the railroad systems, added to the appeal of the trans-Sahel roads.

The first pilgrimages from West Africa by car and train date from the early 1930s. In 1934 for example, Ouage, the village chief of Kanambakachy close to Maradi in Niger, rode his horse to Katsina, where he took a lorry to Kano, from whence he went to Fort Lamy (N'djamena) by truck. In Fort Lamy he boarded a voiture touriste bound for Abeché at the Chad-Sudan border. These voitures touriste were essentially lorries transformed into coaches by having benches installed in the loading bank. In Abéché he changed to a lorry bound for El Obeid. From there he continued by train to Suakin via Khartoum. The whole journey coming and going took him 150 days, where the journey afoot would probably have taken more than double or triple the time. Ouage agreed so much with traveling by car that on his way back he bought a second-hand voiture touriste himself in El Obeid. Unfortunately, the car broke down repeatedly and he had to leave it behind in Kano. ${ }^{52}$

After the Second World War, the transport of pilgrims by motorcar took off in earnest, leading to a heyday decade of overland pilgrimage. There existed a number of companies specialized in the transport of pilgrims by truck or voiture touriste, such as the Nigerian "Tarzan Transport." ${ }^{3}$ The fare of the

50) Baier (1980).

51) http://www.sudanrailways.gov.sd/en/history.htm

52) ANN 4E10.8 Rapport sur les pèlerins revenant de La Mecque 1930-1939.

53) ANN 4E12.14: Rapport de M. Brouin, administrateur chargé d'accompagner un convoi de Pèlerins par voie de terre. 
journey, as well as the roads taken and the needed travel time, depended of course on the point of departure, but also on the means of transport used and partly on the season in which the pilgrims traveled. In French West Africa, two cities functioned as gathering points: Niamey in Niger and Fort Lamy in Chad. Pilgrims would gather in Niamey to travel onwards through Nigeria, making use of the roads and railroads there, converging south to Fort Lamy at the southern shore of Lake Chad, from where the road led to the Sudanese railroad head in El-Obeid. But during the decade between the mid-1940s and mid-1950s, the trans-Sahel road was positioned to the north of the lake, leading through Nguigmi and Mao via Ati to Abéché in the dryer Sahel-Sahara steppes of Wadaï and on to Al Fasher in Darfur. The Muslim lunar calendar is absolute, which means that the month of Dhû l-Hijja, the month of the hajj, shifts through the seasons. In this period, Dhû l-Hijja fell such that West African pilgrims calculating their travels to arrive in time in Mecca to perform the hajj had to travel in the Sahel's rainy season, which turned southern passageways close to the lake into impassable swamps.

I would like to illustrate these developments with the pilgrimages of al-Hajj Alkaidi Touré. Born in Timbuktu around 1898, Alkaidi Touré had moved to Niamey in the early 1920s. There he started a commercial enterprise that would grow so successful that he opened branches in Bamako and Gao. Alkaidi's main activities were import-export and transport, a combination well-known in the Sahel. A Muslim from the prestigious Touré clan of Timbuktu, Alkaidi stood in the West African tradition of Muslim merchants. But from the 2oth century onwards, pilgrimage would become so intimately linked to the identity of these merchants, that they became known as alhazai: hajji's. ${ }^{54}$ In 1938 Alkaidi performed the pilgrimage for the first time, traveling over land. ${ }^{55}$ Not much is known about his first pilgrimage, but his second journey is well documented. Preparations for this journey started in 1945, when Alkaidi requested the importation and purchase of two Citroën T.45 trucks and sufficient gasoil to make the journey. These requests were necessary due to war shortages and denied for the same reason. A year later his request was granted and Touré could set out with his group on August 2, 1946. Touré had married four wives whom he took along on this pilgrimage, together with his relatives and some relatives of his wives. The group also included three affluent traditional chiefs, who each contributed 15,000 Francs to the sustenance of their poorer

\footnotetext{
54) Grégoire (1986).

55) ANN 4E12.3 Pélérinage à la Mecque: dossiers constitués par: Tahirou Made, Abdou Aouta, Elkaidi Touré, Andjer ben Ahmet, Mocktar ben Cheriffe 1938.
} 
fellow travelers, who themselves paid according to their means. ${ }^{56}$ They took the south bound road across Nigeria and Cameroon to Fort Lamy, and from there to El Obeid, where they would take the train to Port Sudan. Alkaidi knew the road, as he had already performed the overland hajj in 1938. He therefore knew approximately how long it would take to reach their goal and when to depart. Their journey would take 42 days from Niamey to Djeddah. Alkaidi was an active member of the Tijaniyya brotherhood and his youngest wife, Madani Sy, had maternal relatives in the area around lake Chad, while from her father's side she was related to the family of Hajj Umar Tall. These affiliations, together with other relations and the connections of the traditional chiefs and marabouts in their convoy ensured lodging and help along the way. ${ }^{57}$ In the decade between the mid-1940s to the mid-1950s, pilgrims to Mecca had to face the rains. Only the stretch between Zaria and Maiduguri in Nigeria was passable. The roads through Chad were mud tracks, changing into sand dunes in Darfur. According to Lamine Touré, Alkaidi's oldest son, who worked as a driver for the family company for many years and who drove one of the trucks on the 1946 journey, the sandy roads in Sudan could only be taken by Ford trucks equipped with a V8 motor. ${ }^{58}$ Alkaidi was forced to rent these Ford trucks in Sudan to travel to El Obeid, leaving his own cars behind. They completed their journey that same year. In 1949, Alkaidi performed the hajj for the third time, this time traveling by airplane. ${ }^{59}$ In 1950, he organized a new pilgrim convoy over land. It seems that Alkaidi wanted to venture out and make the organization of the pilgrimage part of his regular business. Alkaidi had little posters and flyers written in Arabic spread throughout Niger and French Sudan to announce that he would organize a pilgrimage convoy over land, for the sum of 100,000 francs, all included. In exchange Alkaidi would arrange all travel details, including the administrative paperwork and bank details. He left on August 3, 1950 with about 70 people, including a number of traditional chiefs and influential marabouts. Unfortunately, this journey would be less successful despite the fact that Touré disposed of Ford V8 trucks, which he had especially imported. The rains were so heavy that year that even these cars could not pass and the group remained stuck in Abéché. ${ }^{60}$ This debacle led to some quarrels as Alkaidi left the group to perform the hajj himself, although most pilgrims of

\footnotetext{
56) Interview with the Touré family (group interview), Niamey 01/30/2005.

57) Interview with Madani Sy, Niamey o1/30/2005.

58) Interview with Lamine Touré, Niamey.

59) ANN 4E13.7 Télégrammes et corrrespondance divers au sujet de l' organisation du pèlerinage par voie aérienne.

60) Interview with the Touré family (group interview), Niamey 01/30/2005.
} 


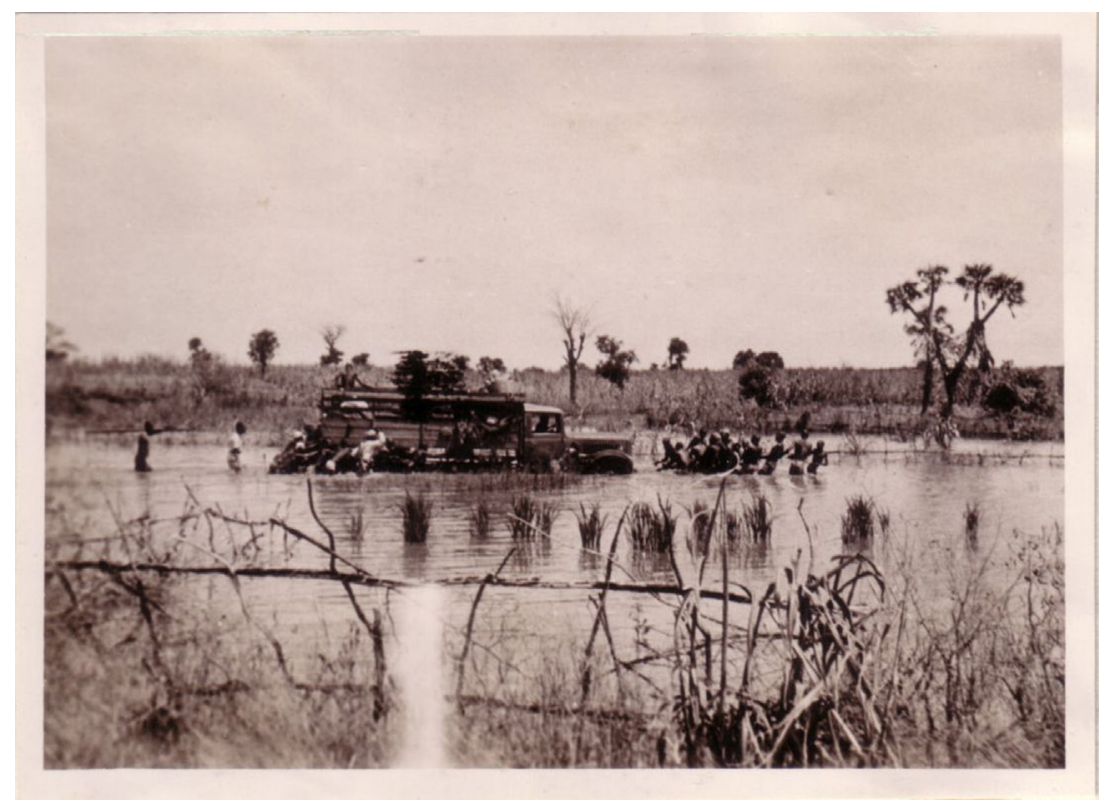

Figure 2: Alkaidi Touré and his men howl a truck through the mud along the Sahel road. Courtesy of the National Archives of Niger. 
his convoy could not follow him and had to return to Fort Lamy ${ }^{61}$ Later in life, in 1967 , Alkaidi would travel to India to visit fellow Tijani sufis whom he had met in Mecca, but that is beyond the scope of this paper.

\section{Changing Times, Changing Space, Changing Roads, Changing Values}

New means of transport altered the urban social and economic topography of the Sahara and Sahel in significant ways. With the replacing of the transSaharan roads by the trans-Sahel road, Saharan towns that had functioned as stops along the way, such as Taroudant in the Moroccan South, Timimoun in the Algerian Touat, or Sebha in the Libyan Fezzan, fell in decline. At the same time, hitherto lost backwaters in the Sahel, such as Mao, Ati, or Rigrig gained significance as the trans-Sahel route developed, while older cities which had been in decline, such as Abéché, the capital of the Wadaï Sultanate, rose to new prominence. But these places too, could dwindle as the roads shifted elsewhere to facilitate the passage of the trucks during the wet season, or as tarmac roads were laid, creating new junctions. This altering social geography became of course even more dramatic with the introduction of aviation. The flights to Mecca in the late 1940 s were maintained with Junkers and DC 3 Dakotas, which had to make regular stops for fuel. Hence, a relatively fine meshed network of airfields existed from which pilgrims could embark. The Douglas DC4 Skymasters and Boeing Constellations of the 1950s had a considerably longer range but they could not yet fly directly from the main capitals of West Africa to Djeddah airport. Hence, a smaller number of larger cities remained functional as main airports for the pilgrimage. These came together in Niamey, which functioned as a hub from where flights were direct to Djeddah. This changed Niamey from a small administrative capital with hardly any local economic significance to a hub for the travel and commerce that always accompanied the pilgrimage. Zinder, until then the commercial capital of Niger and the largest city in the colony, lost importance to dwindle to a regional trade port with Nigeria. From the 1960 on onards long-distance flights from West African capitals directly to Jeddah were normal practice, which again changed the configuration of the pilgrimage. To give one example, Gao airport in the North of present-day Mali was an aeronautical hub between West Africa, Europe, and the Middle East during the 1940 s and 1950s, with flights to Paris, Bamako, Dakar, and Niamey. After independence, the international function of Gao airport was lost, but it

61) Zakari (2011: 167-68). 
remained functional on internal flights until the 1980s, transporting pilgrims first to Bamako, and from there to Djeddah.

The changes in means of transport also reflect changing attitudes towards the hajj and what it represents. In ideology, the members of the 'Umma, the Muslim world community, are equal in the face of God. However, the inequality between pilgrims found expression in their journey to Mecca. In the 19th century all pilgrims, rich or poor, largely had to endure the same hardships on the road, whether trans-Saharan or trans-Sahel. There were of course differences in social and economic standing, which found expression in the pilgrimage caravan. Richer and more powerful pilgrims rode up front, leaving the poorer pilgrims to deal with their dust. Many powerful pilgrims traveled with their servants who labored to their masters' convenience along the way. Then there were differences in lodging and food. ${ }^{62}$ But even though not all could afford to have a camel or other riding mount, all pilgrims, even the richer ones, had to walk at least parts of the road and sand storms or raiding parties were equally unpleasant to all. Thus, all shared equally in the sufferings of the pilgrimage. The new means of transport changed the ideal equality among pilgrims on the hajj, reflecting the inequality in worldly status and buying power in new ways. As a publicity poster of the Air Company UAT read:

A journey to Mecca in great comfort and speed with UAT's modern and powerful Douglas $D C_{4}$ four motor aeroplanes will underline the great prestige of those who sport the title of Hadji ${ }^{63}$

This inequality has now diminished again, as the vast majority of pilgrims today arrive by plane.

The commodification of the hajj journey from the 1930s onwards led to discussions on the merit of pilgrimage and even to a measurable inflation. To the pious, the hajj is intended as a journey combining the physical and the spiritual. Hardship and privation for the love of God on the pilgrimage are essential to strengthen the faith in God and to mortify the flesh. This vision is in sharp contrast to the luxurious and speedy travel of the 2oth century. What, it was now discussed, is the merit of the journey to Mecca by boat, car, or airplane on a spiritual level. Some West African Muslims adopted the view that the hajj was

\footnotetext{
62) Faroqhi (1994).

63) ANN 4E14.03 UAT liste des pelerins aériens $195^{2}$.
} 


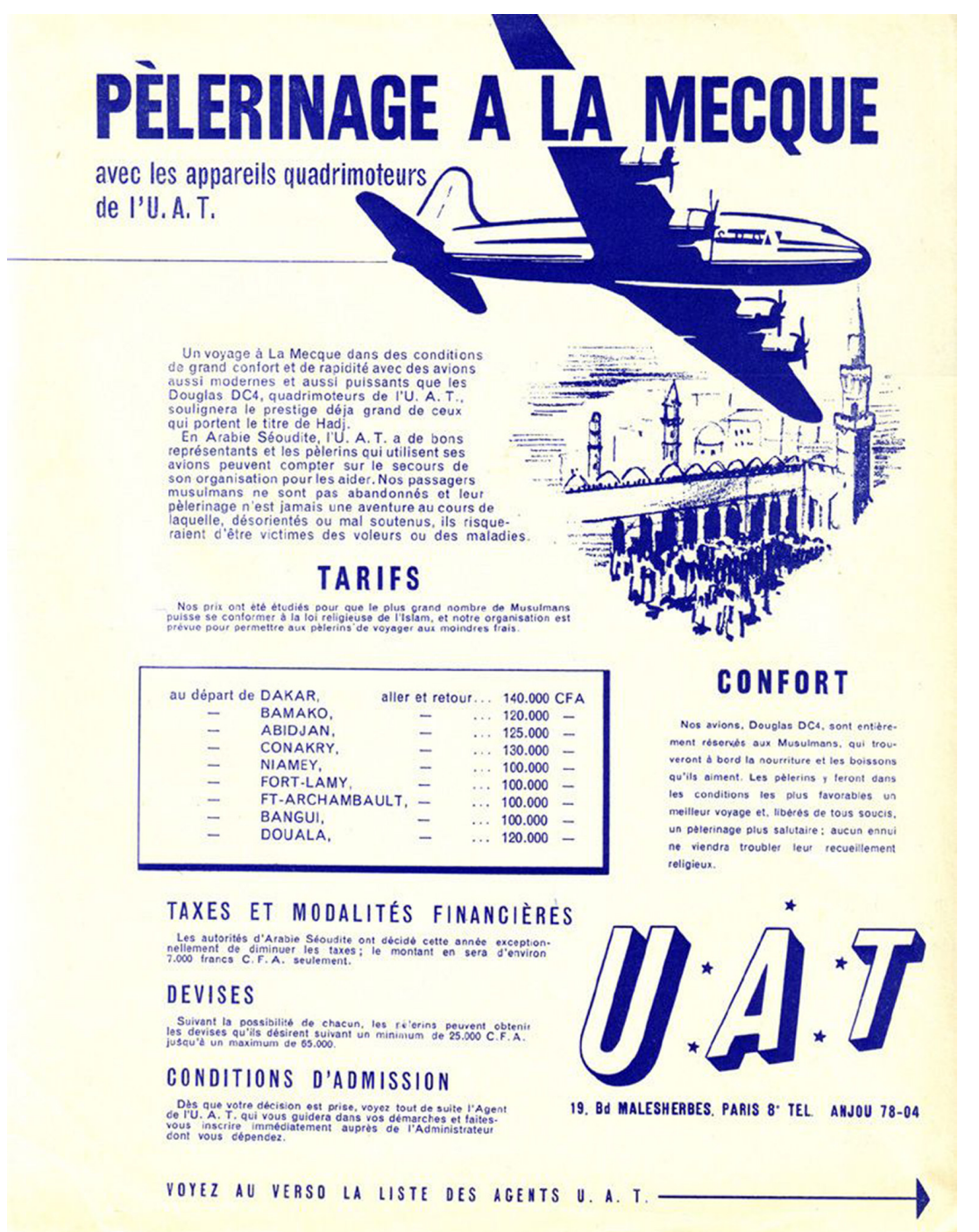

Figure 3: A competitive and non-discriminatory market: U.A.T. publicity poster for an airborne pilgrimage. Courtesy of the National Archives of Niger. 
not fully performed and valid until one had performed the journey three times. ${ }^{64}$ Until today, very pious West Africans hold the hajj to be a journey to be made afoot or at least by car, once seen itself as a luxury form of travel sparking these same discussions. Thus, the overland road has never been totally abandoned, despite the dangers this road now again holds for pilgrims crossing Chad and Sudan. Travel by car, once an innovation, is now an unquestioned merit.

\section{Conclusion}

The 19th and 2oth centuries saw radical changes in the performance of the hajj from West Africa, due to changing political, economic, social, and technical circumstances on a world scale. In the 19th century and before, the vast majority of pilgrims were men from the upper strata of society. Merchants combined the hajj with trade, scholars with study, and rulers with politics. Most combined all three social positions and all three goals with their pilgrimage. Political circumstances worldwide were decisive for the decisions these 19th-century pilgrims made with regards to their itineraries, business ventures, and stays abroad. The globalization of European wars, the transformations and modernization of Muslim powers (both in the Sahel and elsewhere), and especially the start of the European conquest of (North) Africa played a crucial role in their itineraries. But the internationalization of state relations also had an impact. The 1894 international agreements on the transport of pilgrims, including quarantine measures decisively transformed pilgrims' fare and welfare. The changes in (maritime) technique showed their future role, as pilgrims chose to travel with European maritime (steamship) companies from the Mediterranean onwards.

The 2oth century saw even more dramatic changes in the performance of the pilgrimage. After the jihad campaigns of the 19th century had already transformed the religious landscape of the Sahel, the region's inclusion in the world economy and in European empires led to mass conversion to Islam. Combined with new labor relations, new forms of wealth, new state structures, as well as new means of transport, this led to dramatic shifts in pilgrim social demography and to a spectacular growth in their numbers. A new middle class of colonial civil servants and military joined the old and partly transformed elite of merchants, scholars, and leaders. More importantly a new class of agricultural laborers joined these upper strata of society. While new labor-intensive

64) Gouilly (1952: 193). 
cash crops such as peanuts and especially cotton were introduced, plantation slavery was abolished, increasing the need for labor in the Sahel, but also freeing laborers to travel where salaries were highest.

The mobility of labor and religion was greatly facilitated by the increasing availability of mechanical means of transport. Their presence, especially that of the fixed railroads, radically altered the roads pilgrims took, away from the Sahara, toward the Sahel itself. This in turn reshaped the urban economic and social topography of the Sahara and Sahel further, as cities rose and fell in importance along the different roads taken. The rapidity and scale of mass transport led to a spectacular fall in the price of the pilgrimage, especially when we do not only take the travel fare into consideration, but also the price of absence at home. This latter decrease both in time and in money, as well as the labor migration which many combined with the pilgrimage, placed the hajj in reach of West African Women, whose participation rose from close to zero to over half of the total amount of pilgrims at present. The changes in means of transport also reflect changing attitudes towards the hajj and what it represents. To the pious, the hajj is intended as a journey combining the physical and the spiritual. Hardship and privation for the love of God on the pilgrimage are essential to strengthen the faith in God and to mortify the flesh. The mobile lifestyle is part of a vision on the transient state of the human being between this world and the next. This vision is in sharp contrast to the luxurious and speedy travel of those who come by boat or airplane.

Studying its interference in the organization of the hajj provides insight into the transformation of the colonial and post-colonial state, as it shifted its focus from domination and control to welfare and patronage. In many ways, the organization of the hajj reflects the organization of political patronage in the African colony and post-colony, and the aspirations to rationalize and modernize the religious domain in Africa and the Middle East. In the 19th century knowledge of international politics, the situation on the road and the required ritual prayers were necessary to perform the hajj. In the 2oth century knowledge of ritual remained necessary, but it was complemented with knowledge of and compliance with state bureaucracy, rather than security and politics. 'Illegal' pilgrimage journeys became more and more difficult from the late 1930s onwards, with the construction of the state in Saudi Arabia and the modernization of state services in French West Africa, Egypt, and Sudan.

As a last point, consider this simple observation. In the $1830 \mathrm{oshmad}$ ibn Thuwair al-Janna traveled only once to Mecca, a single journey taking him four years of his life and he did not linger. Between 1938 and 1950, a bit more than a decade, Alkaidi Touré performed the hajj four times, traveling from and to his 
hometown of Niamey every journey. By the mid-2oth century, the hajj was no longer the journey of a lifetime as it had been a short century earlier.

\section{References}

al-Naqar, Umar. 1972. The Pilgrimage Tradition in West Africa, an Historical Study with Special Reference to the Nineteenth Century. Khartoum: Khartoum University Press.

Amselle, Jean-Loup. 1977. Les Négociants De La Savane: Histoire Et Organisation Sociale Des Kooroko (Mali). Paris: Editions Anthropos.

Baier, Stephen. 1980. An Economic History of Central Niger. Oxford: Clarendon Press.

Bawa Yamba, C. 1995. Permanent Pilgrims: The Role of Pilgrimage in the Lives of West African Muslims in Sudan. Vol. 15, International African Library. Edinburgh: Edinburgh University Press.

Bianchi, Robert. 2004. Guest of God, Pilgrimage and Politics in the Islamic World. Oxford: Oxford University Press.

Birks, J.S. 1975. "Overland Pilgrimage in the Savanna Lands of Africa." In People on the Move, Studies on Internal Migration, edited by L. Kozinski and R. Prothero, 297-308. London: Methuen \& Co.

—. 1977. "The Mecca Pilgrimage by West African Pastoral Nomads." Journal of Modern African Studies 15, no. 1: 47-58.

—. 1978. Across the Savannas to Mecca: The Overland Pilgrimage Route from West Africa. London: Hurst.

Botte, Roger. 2010. Esclavages et abolitions en terres d'Islam. Paris: André Versaille éditeur.

Boubeker, Hajj, and Rouzee. 1915. "Voyage d'un Soudanais à la Mecque en 1816." La Revue des Colonies et des Questions Coloniales 9, pp. 227-31.

Christelow, Allan. 1987. "Political Ends and Means of Transport in the Colonial North African Pilgrimage." The Maghreb Review 12, no. 3/4: 84-89.

Cooper, Barbara. 1999. "The Strength in the Song: Muslim Personhood, Audible Capital, and Hausa Women's Performance of the Hajj." Social Text 17, no. 3: 87-109.

Cruise O'brien, Donal. 1971. The Mourides of Senegal: The Political and Economic Organization of an Islamic Brotherhood. Oxford: Clarendon Press.

Faroqhi, Suraiya. 1994. Pilgrims \& Sultans - the Haj under the Ottomans. London: I.B. Tauris.

Fisher, Allan, and Humphrey Fisher. 1970. Slavery and Muslim Society in Africa: The Institution in Saharan and Sudanic Africa, and the Trans-Saharan Trade. London: Hurst.

Fisher, Humphrey. 1988. Slavery in the History of Muslim Black Africa. London: Hurst.

Gary-Tounkara, Daouda. 2003. "Circulation et réseaux migratoires soudanais-maliens en Afrique de l'ouest (1932-1974)." Migrations Société 15, no. 90: 67-82.

Gouilly, Alphonse. 1952. L'Islam dans l'Afrique occidentale francaise. Paris: Editions Larose.

Grégoire, Emmanuel. 1986. Les Alhazai de Maradi (Niger): histoire d'un groupe de riches marchands sahéliens. Paris: Editions de l'ORSTOM.

'Hadjdj,' Shorter Encyclopedia of Islam (Leiden: Brill 1953), 121-125.

Hino, Shun'ya. 1986. "Pilgrimage and Migration of the West African Muslims: A Case Study of the Fellata People in the Sudan." In Sudan Sahel Studies, edited by Morimichi Tomikawa, 15-109. Tokyo: Institute for the Study of Languages and Cultures of Asia and Africa.

Hock, Carsten. 1999. Fliegen die Seelen der Heiligen? Muslimische Reform und staatliche Autorität in der Republik Mali seit 196o. Berlin: Klaus Schwartz Verlag. 
Hopkins, A.G. 1973. An Economic History of West Africa. London: Longman.

- 2009. "The New Economic History of Africa." The Journal of African History 50, no. 2: 155-77. Juynboll, Th. 1930. Handleiding tot de kennis van de Mohammedaansche wet volgens de leer der Sjâfi'itische school. Leiden: Brill.

Klein, Martin. 1998. Slavery and Colonial Rule in French West Africa. Cambridge: Cambridge University Press.

Launay, Robert, and Benjamin Soares. 1999. "The Formation of an 'Islamic Sphere' in French Colonial West Africa." Economy and Society 28: 497-519.

Loimeier, Roman. 1988. “Das 'Nigerian Pilgrimage Scheme': Zum Versuch, den Hagg in Nigeria zu Organisieren." Afrika Spektrum 23, no. 2: 201-14.

Lovejoy, Paul. 2005. Slavery, Commerce and Production in the Sokoto Caliphate of West Africa Trenton: Africa World Press.

Lydon, Ghislaine. 2004. "Inkwells of the Sahara: Reflections on the Production of Islamic Knowledge in Bilâd Shinqît." In The Transmission of Learning in Islamic Africa, edited by Scott Reese, 39-71. Leiden: Brill.

- 2009. On Trans-Saharan Trails. Islamic Law, Trade Networks, and Cross-Cultural Exchange in Nineteenth-Century Western Africa. Cambridge: Cambridge University Press.

'Mahmal,' Encyclopedia of Islam vol. 6 (Leiden: Brill 1986): 44-46.

Mann, Gregory, and Baz Lecocq. 2007. "Between Empire, Umma, and the Muslim Third World: The French Union and African Pilgrims to Mecca, 1946-1958." Comparative Studies of South Asia, Africa and the Middle East 27, no. 2: 367-83.

Mbacké, Khadim. 2005. Le pèlerinage aux lieux saints de l'Islam: participation sénégalaise 18861986. Dakar: Presses Universitaires de Dakar.

Medugbon, A.K. 1982. "The Nigerian Pilgrimage to Mecca." In Redistribution of Population in Africa, edited by J. Clarke and L. Kosinski. London: Heinemann.

Norris, Harry T. 1977. The Pilgrimage of Ahmad, Son of the Little Bird of Paradise - an Account of a 19th Century Pilgrimage from Mauritania to Mecca. Warminster: Aris \& Phillips.

Pervillé, Guy. 1997. “Comment appeler les habitants de l'Algérie avant la définition légale d'une nationalité algérienne?" Cahiers de la Méditerranée 54: 55-60.

Peterson, Brian. 2011. Islamization from Below: The Making of Muslim Communities in Rural French Sudan, 1880-196o. New Haven: Yale University Press.

Sabini, John. 1981. Armies in the Sand - the Struggle for Mecca and Medina. London: Thames and Hudson.

Searcy, Kim. 2010. “The Sudanese Mahdi's Attitudes toward Slavery and Emancipation." In Islamic Africa 1, no. 1: $63-83$.

Snouck Hurgronje, Christiaan. 2007. Mekka in the Latter Part of the 19th Century. Translated by J.H. Monahan. 2nd ed. Leiden: Brill.

Triaud, Jean-Louis. 1997. “Le crépuscule des ‘Affaires Musulmanes' en AOF, 1950-1956.” In Le temps des marabouts - itinéraires et stratégies islamiques en Afrique occidentale française V. 1880-1960, edited by David Robinson and Jean-Louis Triaud, 493-519. Paris: Karthala.

Weil, Patrick. 2003. "Le statut des Musulmans en Algérie coloniale: une nationalité française dénaturée." In EUI Working Paper HEC. Florence: European University Institute, Department of History and Civilization.

Zakari, Maïkoréma. 2010. L'islam dans l'espace nigérien.Tome 1: des origines (viie siècle) à 1960. Paris: L’Harmattan. 